\title{
KAJIAN PSIKOLOGI SASTRA NOVEL BIDADARI BERMATA BENING KARYA HABIBURRAHMAN EL SHIRAZY DAN NILAI PENDIDIKAN KARAKTER TOKOH DALAM PERSPEKTIF PEMBELAJARAN BAHASA INDONESIA
}

\author{
Novia Rahmah Bastian, Suyitno, Chafit Ulya \\ Universitas Sebelas Maret \\ Surel: noviarahmahbastian@student.uns.ac.id
}

\begin{abstract}
Abstrak: Tujuan penelitian ini adalah untuk mendeskripsikan dan menjelaskan: (1) unsur intrinsik novel Bidadari Bermata Bening; (2) beban psikologis tokoh utama; (3) nilai-nilai pendidikan karakter; (4) kedudukan novel Bidadari Bermata Bening karya Habiburrahman El-Shirazy dalam perspektif pembelajaran Bahasa Indonesia. Penelitian ini dilakukan dengan metode kualitatif deskriptif dan menggunakan pendekatan psikologi sastra. Hasil penelitian ini menunjukkan bahwa: (1) setiap unsur novel memiliki keterkaitan dengan unsur yang lain sehingga membuat cerita yang padu. (2) analisis psikologi untuk beban psikologis tokoh utama menggunakan teori analisis Sigmund Freud yang meliputi tiga unsur kepribadian yaitu id, ego, dan superego. (3) nilai-nilai pendidikan karakter yang terdapat dalam novel meliputi religius, jujur, toleransi, disiplin, kerja keras, kreatif, mandiri, rasa ingin tahu, menghargai prestasi, bersahabat/ komunikatif, cinta damai, peduli sosial, dan tanggung jawab. (4) novel Bidadari Bermata Bening karya Habiburrahman ElShirazy dapat digunakan sebagai materi pembelajaran Bahasa Indonesia.
\end{abstract}

Kata kunci: novel, psikologi sastra, nilai pendidikan karakter, perspektif pembelajaran Bahasa Indonesia

\section{STUDY OF LITERATURE PSYCHOLOGICAL BIDADARI BERMATA BENING NOVEL BY HABIBURRAHMAN EL SHIRAZY AND CHARACTER EDUCATION VALUE IN PERSPECTIVE OF INDONESIAN LANGUAGE LEARNING}

\begin{abstract}
The purpose of this research is to describe and explain: (1) intrinsic element of novel Bidadari Bermata Bening; (2) psychological burden of the main character; (3) character education values; (4) the position of novel Bidadari Eye Bening by Habiburrahman El-Shirazy in Indonesian Language Learning perspective. This research was conducted by qualitative descriptive method and using psychology approach of literature. The results of this study indicate that: (1) each element of the novel has relevance with other elements so as to make the story coherent. (2) psychological analysis for the psychological burden of the main character using Sigmund Freud's theory of analysis which includes the three elements of personality namely id, ego, and superego. (3) the values of character education contained in the novel include religious, honest, tolerance, discipline, hard work, creative, independent, curiosity, respectful achievement, friendly / communicative, peace loving, social caring, and responsibility. (4) novel Bidadari Bermata Bening by Habiburrahman El Shirazy can be used as Learning material of Bahasa Indonesia.
\end{abstract}

Keywords: novel, literary psychology, character education value, Indonesian learning perspective

\section{PENDAHULUAN}

Karya sastra adalah sesuatu yang indah yang berasal dari hasil cipta, rasa, dan karsa manusia yang dapat mencerminkan masyarakat tempat karya tersebut dilahirkan. Karya sastra yang baik mampu menjadi refleksi dan sanggup memberikan sumbangan untuk masyarakat penikmatnya, baik itu yang bersifat rekreatif maupun edukatif. Selain itu, juga bisa menggambarkan bagaimana hubungan 
manusia dengan Tuhan, sesama manusia, dan manusia dengan lingkungan.

Karya sastra dianggap sebagai hasil aktivitas penulis yang berkaitan dengan gejala-gejala kejiwaan. Setiap tokoh yang ditampilkan pengarang dalam sebuah karya sastra adalah tokoh yang mempunyai jiwa dalam menghadapi masalah-masalah kehidupan. Apabila tokoh yang ditampilkan dalam karya sastra adalah tokoh yang berjiwa dan gejolak dirinya saat bersentuhan langsung dengan masalah yang menyangkut kehidupannya, kehidupan yang dijalani akan membentuk jiwa tokoh menjadi kuat, lemah, menyesuaikan diri dalam menjalani roda kehidupannya (Ratna, 2004: 62).

Nurgiyantoro mengatakan bahwa novel merupakan sebuah karya sastra fiksi yang menawarkan sebuah dunia yang berisi model kehidupan yang diidealkan, dunia imajinasi, yang dibangun melalui berbagai unsur intrinsiknya (2012: 4). Novel menyajikan berbagai kisah yang bisa membuat pembaca berimajinasi dan masuk dalam cerita novel tersebut. Cerita dalam novel dapat hidup dengan kehadiran tokoh-tokoh dengan berbagai karakteristiknya. Dengan kata lain, pembaca dapat mengerti isi cerita ketika mengetahui kondisi psikologis tokoh dalam novel. Oleh karena itu, hubungan antara sastra dan psikologi sangat erat sehingga melebur dan melahirkan ilmu baru disebut psikologi sastra.

Psikologi sastra adalah analisis teks dengan mempertimbangkan relevansi dan peranan studi psikologi (Budiantoro \& Mardianto, 2016: 47). Tujuan psikologi sastra adalah memahami aspek-aspek kejiwaan yang terkandung di dalam suatu karya (Minderop, 2013: 54). Emzir dan Rohman mengatakan bahwa analisis psikologi terhadap karya sasta, terutama fiksi dan drama, tidak terlalu berlebihan karena baik sastra maupun psikologi samasama membicarakan manusia (2013: 186).

Novel sebagai salah satu bentuk karya sastra dapat digunakan sebagai media untuk mengungkapkan nilai-nilai yang terdapat dalam masayarakat.Tidak sedikit pembaca novel yang megikuti gaya bicara, busana, atau perilaku tokoh setelah membaca dan memahami sebuah novel. Melalui novel, peserta didik dapat belajar memahami kehidupan orang lain, bukan hanya dunia mereka sendiri. Oleh karena itu, tidak menutup kemungkinan melalui psikologi sastra seorang pendidik dapat menanamkan nilai-nilai pendidikan karakter yang terdapat dalam novel.

Kisah di dalam novel Bidadari Bermata Bening karya Habiburrahman El Shirazy ini merupakan potret kehidupan anak manusia yang tak lepas dari berbagai ujian dan godaan. Tokoh utama dalam novel tersebut adalah Ayna. Dia selalu sabar atas segala cobaan yang dialaminya. Bahkan selalu tegar, rajin bekerja, rajin beribadah, dan rajin pula belajar untuk mencapai cita-cita yang didambakannya.

Novel Bidadari Bermata Bening banyak memberikan dorongan untuk mencapai cita-cita dalam dunia pendidikan dan keagamaan, menyuratkan banyak sekali muatan motivasi perjalanan panjang tanpa mengenal keputusasaan. Sikap yang dijalani tokoh utama dalam mencapai prestasi pada novel ini baik dicontoh bagi siswa. Di sisi lain novel ini bisa menjadi renungan bagi siswa untuk melanjutkan ke jenjang pendidikan yang lebih tinggi dan cara hidup mandiri dengan selalu menghormati kepada orang yang lebih tua, berperilaku sopan, serta menghargai kepada orang yang lebih muda.

Berdasarkan uraian di atas, peneliti bermaksud untuk mengkaji karakter tokoh utama dalam novel Bidadari Bermata Bening karya Habiburrahman El Shirazy dengan pendekatan psikologi sastra dan mencari nilai pendidikan karakter novel serta menentukan kedudukan novel tersebut dalam perspektif pembelajaran Bahasa Indonesia.

\section{METODE PENELITIAN}

Penelitian ini dilaksanakan selama enam bulan, yaitu dari bulan November 2017 sampai dengan April 2018. Penelitian 
ini merupakan penelitian kualitatif deskriptif dengan menggunakan pendekatan psikologi sastra. Data dan sumber data yang digunakan adalah kata, frasa, kalimat, paragraf/alinea, wacana, yang ada dalam novel Bidadari Bermata Bening karya Habiburrahman El Shirazy yang menunjukkan kepribadian tokoh. Selain itu data diperoleh juga dari hasil wawancara dengan guru, dan siswa SMP Negeri 1 Banyudono yang telah membaca novel Bidadari Bermata Bening. Pengambilan subjek penelitian dilakukan dengan teknik purposive sampling. Pengumpulan data dilakukan dengan analisis dokumen dan wawancara. Uji validitas data dalam penelitian ini menggunakan triangulasi triangulasi metode. Teknik analisis data yang digunakan adalah teknik analisis model mengalir yang dikemukakan oleh Miles dan Huberman.

\section{HASIL PENELITIAN DAN PEMBAHASAN}

\section{Struktur Novel Bidadari Bermata Bening Karya Habiburrahman El Shirazy}

Novel sebagai karya sastra fiksi memiliki unsur-unsur pembangun yang meliputi tema, tokoh dan penokohan, alur atau plot, latar, dan sudut pandang, Berikut struktur yang dianalisis dalam novel Bidadari Bermata Bening.

\section{Tema}

Tema adalah sesuatu yang menjadi dasar cerita. Ia selalu berkaitan dengan berbagai pengalaman kehidupan. Untuk mengetahui tema dalam sebuah novel harus dilihat dari keseluruhan cerita, tidak hanya dari potongan-potongan cerita. Tema yang diangkat dalam novel Bidadari Bermata Bening karya Habiburrahman El Shirazy adalah kegigihan dan keikhlasan dalam menghadapi segala cobaan. Hal ini dapat dilihat dari kisah beberapa tokoh yang pada akhirnya menemukan dunia yang berbeda dalam sebuah sirkus. Hal tersebut dapat terlihat pada cuplikan berikut: "sambil menyuapi Ayna menceritakan perjalanan hidupnya. Bagaimana ia hidup bersama Yoyok dari keluarga yang tidak beres. Bagaimana ia memberi syarat kepada Yoyok. Bagaimana ia dicerai Yoyok dan jadi nyaris jadi korban Bandot Tua Brams Margojaduk. Bagaimana ia melarikan diri hingga akhirya terdampar di Bandung. Bagaimana rasanya hidup luntanglantung jadi gelandangan di Bandung. Bagaimana rasanya makan nasi sisa orang lain yang ia ambil dari tempat sampah. Hingga ia bertemu $\mathrm{Bu}$ Rosidah yang memperlakukan dirinya seperti anaknya sendiri. Bagaimana ia berkenalan dengan dunia bisnis, belajar bisnis dan menekuni dunia bisnis. Ia membat usaha 'Roti Barokah' dan juga mendirikan rumah penampungan anak jalanan bersama para dermawan dan orang baik di Bogor..." (BBB, 2017: 293).

Ayna adalah gadis yang sangat tegar dalam menjalani roda kehidupan. Meski ia hidup sebatangkara, kegigihan dan rasa pantang menyerahnya seolah mampu membuat dia selalu semangat dalam mencapai cita-citanya.

\section{Alur atau Plot}

Cerita dalam novel Bidadari Bermata Bening karya Habiburrahman El Shirazy ini mempunyai alur penulisan maju mundur. Bagian awal novel ini menceritakan tentang tokoh utama yaitu Ayna sebagai khadimah yang mempunyai prestasi terbaik se-pesantren dan bahkan terbaik se-Jawa Tengah, selanjutnya pembaca diajak untuk kembali ke masa lalu saat ibu Ayna bekerja sebagai TKW dan tentang kisah lama keluarga Ayna. Cerita selanjutnya berkisah tentang jalan cerita Ayna dalam menjalani hidup setelah keluar dari Pesantren hingga ia kembali lagi ke pesantren. Penggunaan tahapan alur dalam novel dilakukan secara bertahap, mulai dari eksposisi, inciting moment, 
rising action, complication, climax, falling action, dan denouement.

Tahap eksposisi dimulai saat pengarang memaparkan latar tempat novel di Pesantren sebagai latar tempat tokoh utama. Pada bagian awal ini pengarang juga mejelaskan bahwa Ayna (tokoh utama) adalah seorang khadimah yakni pembantu Ibu Nyai di Pesantren. Pada tahap Inciting moment, kemunculan konflik ditandai dengan munculnya tokoh Neneng yang menghina ibu Ayna sebagai orang rendahan yang bekerja TKW di Arab. Ayna merasa nama keluarganya seperti diinjak-injak. Namun, sikap sabar yang ia miliki mampu meredam kemarahannya terhadap Neneng. Konflik semakin meningkat pada tahap rising action. Pada tahap tersebut, Ayna mendapat infomasi dari Zulfa bahwa Neneng menghina orang tua Ayna di depan semua santri dan menuduh Ayna mendapatkan peringkat terbaik UN nomor satu se-Jawa Tengah karena mendapat bocoran soal. Kemarahan Ayna sudah tidak dapat diredam lagi. Ia tidak terima jika ibunya dihina oleh Neneng, hingga pertengkaran Ayna dan Neneng terjadi. Tahap complication terjadi ketika keluarga Ayna satu-satunya yakni Pakde Darsun dan istrinya tidak mau hadir sebagai wali Ayna di acara pelepasan sekolah. Permasalahan tidak hanya sampai di situ, muncul lagi masalah baru. Lamaran dari Kyai Yusuf Badrujja ditolak oleh keluarga Ayna. Pakde dan budenya melarang Ayna menikah dengan seorang duda. Bersamaan dengan perjodohan tersebut, tanpa sepengetahuan siapapun Ayna juga dilamar secara khusus oleh Gus Afif. Ia adalah anak Kyai Sobron yang selama ini diamdiam Ayna idolakan. Ayna tidak menyangka bahwa Gus Afif ternyata juga mencintainya dan serius untuk memperistrinya. Konflik mencapai puncaknya (climax) ketika lamaran yang dinantikan Ayna dari keluarga Gus Afif tak kunjung datang. Akhirnya Ayna terpaksa harus mau untuk menikah dengan pilihan pakdenya, yakni seorang anggota DPRD bernama Yoyok yang diketahui bahwa keluarga Yoyok adalah keluarga yang licik dan sering melakukan korupsi. Tahap falling action terjadi pada saat Ayna diminta untuk bercerai dengan Yoyok karena ia terjerat kasus korupsi, dan bersedia untuk menikah lagi dengan orang yang bisa menjamin bebasnya Yoyok dan semua pengikutnya. Tanpa sepengetahuan siapapun Ayna kabur dari rumah dan pergi merantau. Pada tahap denouement, konflik mulai mereda. Diceritakan saat pertemuan Ayna dengan Ibu Nyai karena keadaan Bu Nyai yang sudah kritis tetapi masih sangat merindukan kehadiran Ayna. Bu Nyai sangat menginginkan Ayna bisa menikah dengan Gus Afif. Ibu Nyai masih melihat rasa cinta yang besar antara Gus Afif dan Ayna. Semua pihak setuju atas pernikahan Ayna dan Gus Afif. Akhirnya mereka pun menikah dan hidup bahagia bersama.

\section{Tokoh dan Penokohan}

Berdasarkan perannya, tokoh dalam novel terdiri dari tokoh utama dan tokoh bawahan. Namun, dalam penelitian ini peneliti fokus meneliti penokohan pada tokoh utama. Tokoh utama dalam novel Bidadari Bermata Bening meliputi tokoh utama protagonis (Ayna), tokoh utama antagonis (Pakde Darsun), dan tokoh bawahan meliputi tokoh andalan, tokoh tambahan, dan tokoh lataran.

Tokoh utama protagonis dalam novel Bidadari Bermata Bening memiliki watak pandai, religius, mandiri dan pantang menyerah. Ayna hidup di pesantren tidak hanya menjadi santri, namun juga menjadi seorang khadimah (pembantu perempuan) di rumah Bu Nyai. Ayna menjadi santriwati terbaik dengan nilai UN nomor satu se-Jawa Tengah. Berikut salah satu cuplikan yang menggambarkan hal tersebut.

"Alhamdulillah saya lulusan terbaik di sekolah saat saya SMP. Saya juga pernah juara karate se-Kabupaten. Saya pernah juara hafalan juz 'amma juga saat masih SMP. Ketika masuk pesantren dan lanjut di Madrasah Aliyah, tahun pertama 
saya masuk tiga besar. Setelah itu biasa saja sebab saya banyak kerja menjadi khadimah seperti sudah saya ceritakan. Alhamdulillah saat Ujian Nasional, saya diberi waktu untuk fokus belajar oleh $\mathrm{Bu}$ Nyai dan Pak Kyai selama dua bulan. Dan nilai UN saya terbaik se-Jawa Tengah dan nomor sepuluh seIndonesia." (BBB, 2017: 257).

Tokoh Antagonis dalam novel ini adalah Pakde Ayna bernama Mat Darsun. Pakde adalah saudara tiri ibu Ayna, ia orang yang serakah terhadap harta. Pakde menjodohkan Ayna dengan tujuan politik jika ia berhasil menikahkan Yoyok dengan Ayna, seperti pada cuplikan berikut.

Ia mendapat bocoran bahwa Pak Kusmono memaksa Yoyok menikah dengan tujuan utamanya adalah politik. Yoyok yang sekarang menjadi anggota DPRD dan menjadi pengurus sebuah partai, telah digadang untuk maju sebagai calon Bupati di daerah yang mayoritasnya kaum santri. Maka untuk meningkatkan citra harus dicari istri yang santri. Tidak hanya santri tapi juga istimewa. Begitu Pak Kusmono baca di koran seorang santriwati di Magelang asli Kaliwenang Grobogan punya prestasi istimewa langsung diincarnya. Bagai sumbu ketemu tutup, ternyata gadis itu yang tak lain Ayna- adalah keponakan Pak Darsun. Pak Darsun dan istrinya bersedia menjamin perjodohan Yoyok dengan Ayna dengan imbalan akan dijadikan lurah di Kaliwenang. (BBB, 2017: 191).

Tokoh bawahan yang terdiri dari tokoh andalan, tokoh tambahan, dan tokoh lataran, turut menghiasi jalannya cerita pada novel ini sehingga mampu memperkuat pembaca dalam memahami alur cerita.

\section{Latar atau Setting}

Latar tempat yang digunakan dalam novel Bidadari Bermata Bening disebutkan dengan jelas sehingga pembaca mampu membayangkan di mana letak tempat kejadian suatu peristiwa tersebut. Berikut salah satu cuplikan yang menunjukkan latar tempat terjadinya suatu peristiwa.

"Mobil Innova Silver itu memasuki halaman sebuah rumah yang asri. Di samping rumah ada gerbang kecil, di atas gerbang ada plang bertuliskan "Pesantren Mahasiswa Al Manhal Al Islami”. (BBB, 2017: 82).

Latar waktu yang digunakan di dalam novel ini ditunjukkan dengan kata penunjuk waktu seperti pagi, sore, dan malam hari. Perbedaan waktu diceritakan dengan menggunakan penunjuk waktu, seperti malam ini, pagi itu, dan lain-lain.

Perbedaan waktu juga ditunjukkan dengan menyebutkan usia tokoh utama, yaitu Ayna. Selain itu, dalam novel ini terdapat urutan waktu seperti keesokan hari, pada malam hari, dan lain-lain. Hal tersebut tampak dari cuplikan berikut.

"...Aku tahu, sebelas hari yang lalu umur kamu masuk 19 tahun. Dan satu bulan lagi umurku masuk 21 tahun." (BBB, 2017: 151)

Sudah tiga bulan Gus Afif menjalani hidup normal di pesantren. (BBB, 2017: 209)

Malam itu langit biru tua. Bintang gemintang memamerkan kerlipnya. Udara sejuk mengalir dari lereng Merbabu menyapu kawasan Grabag dan Secang. (BBB, 2017: 44)

Latar sosial yang ada dalam novel

Bidadari Bermata Bening ini adalah mengenai kehidupan Ayna di Pesantren. Meskipun Ayna menjadi seorang khadimah (pembantu perempuan) ia dapat menjunjung nama baiknya karena ia mampu memperoleh prestasi terbaik di pesantren. Ayna juga merupakan orang yang cekatan dalam bekerja, semua yang dilakukannya membuat orang lain yang berada di sekitarnya senang. Hal ini digambarkan pada kutipan sebagai berikut: Ayna dan tiga orang santriwati khadimah Bu Nyai melayani para santriwati dengan cekatan. Wajah 
Ayna tampak lebih bercahaya dibandingkan ketiga temannya... (BBB, 2017: 2).

Tak terasa air mata Mbak Ningrum, Mbak Romlah, dan Mbak Titin meleleh haru. Baru kali ini ada seorang khadimah bisa meraih nilai tertinggi di pesantren. Ayna seolaholah mewakili mereka. Ayna bangkit dari sujud syukurnya dan langsung memeluk Mbak Ningrum. (BBB, 2017: 13)

\section{Sudut Pandang}

Sudut pandang yang digunakan dalam novel Bidadari Bermata Bening yang digambarkan oleh pengarang yaitu menggunakan gaya eksternal yang menampilkan gagasan dari luar tokohtokohnya. Dibuktikan pada kutipan berikut:

Ayna mendengar obrolan itu, tapi ia pura-pura tidak dengar. Selama mereka tidak ada yang benar-benar kurang ajar, ia tidak akan meladeni. Jika sedikit saja berbuat kurang ajar, meski Cuma sekadar mencolek, ia akan menghajarnya. Dan ia sangat yakin orang-orang pasar akan membelanya, sebab mereka sangat menghormati Kyai Sobron Ahsan Muslim (BBB, 2017: 7).

Kutipan di atas membuktikan bahwa pencerita sebagai orang yang serba tahu di luar tokoh. Pencerita mengemukakan gagasan-gagasan tentang tokoh, namun pencerita sendiri tidak ikut menjadi bagian dari cerita tersebut.

Sesuai dengan pendapat Teeuw (2015: 97) yang mengatakan bahwa proses interpretasi yang bertangga berdasarkan asumsi atau konvensi ataupun aksioma bahwa teks yang dibaca mempunyai kesatuan, keseluruhan, kebulatan makna dan koherensi intrinsik. Unsur-unsur yang membangun cerita dalam novel Sirkus Pohon karya Andrea Hirata memiliki keterkaitan yang padu sehingga menjadikan novel ini sebagai karya sastra yang baik. Hubungan unsur pembangun dalam novel memberikan pemahaman yang utuh bagi pembaca.

\section{Amanat}

Amanat adalah pesan yang ingin disampaikan pengarang kepada pembaca. Di dalam novel ini amanat yang dipergunakan adalah secara implisit, yaitu pengarang mengemukakan pesannya secara tidak langsung.

Amanat yang terdapat dalam novel Bidadari Bermata Bening adalah Tokoh utama selalu bekerja keras dan mencari ilmu di mana pun untuk mencapai cita-cita. Ayna senantiasa mendekatkan diri kepada Sang Pencipta agar selalu diberikan kemudahan dalam segala urusan kapan pun dan di mana pun. Dengan begitu setiap kita akan melangkah maka akan selalu diberikan yang terbaik. Novel ini juga memberikan contoh kepada pembaca yakni sebagai anak harus selalu menurut kepada orang yang lebih tua. Bagaimanapun seorang anak apabila orang tua mempunyai kesalahan, sikap anak seharusnya mengingatkan kesalahan orang tua.

\section{Beban Psikologis Tokoh Utama Novel Bidadari Bermata Bening Karya Habiburrahman El Shirazy}

Novel Bidadari Bermata Bening karya Habiburrahman El Shirazy ini menggambarkan sebuah novel yang menceritakan beban psikologi atau tekanan batin yang dialami oleh tokoh utama yaitu Ayna.

Beban psikologis pada tokoh utama novel Bidadari Bermata Bening diteliti dengan pelaksanaan perwatakan yang digambarkan memiliki perkembangan konflik yang dipengaruhi oleh faktor internal maupun eksternal. Pembahasan beban psikologis pada tokoh dalam novel Bidadari Bermata Bening karya Habiburrahman, tidak semua tokoh yang terdapat dalam cerita tersebut diteliti, melainkan hanya beban psikologis pada tokoh utama, yaitu Ayna saja. Seperti telah dijabarkan pada bab sebelumnya, analisis psikologi untuk karakteristik kejiwaan ini 
menggunakan teori analisis Sigmund Freud yang meliputi tiga unsur kepribadian yaitu $i d$, ego, dan superego.

Tokoh utama protagonis memiliki ketiga unsur kepribadian id, ego, dan superego. Keinginan dan tindakannya selalu diimbangi dengan hadirnya superego. Oleh karena itu, tokoh protagonis dalam novel Bidadari Bermata Bening lebih berhati-hati dalam bertindak dan lebih mempertimbangkan baik dan buruknya. Hal tersebut dapat dilihat pada cuplikan berikut.

Tubuh Ayna bergetar hebat tapi dia berusaha keras menguasai dirinya. Ingin rasanya menonjok dan menendang mertuanya itu. Ia merasa benar-benar dihina. Mertua mana yang rela menjual anak menantunya kepada lelaki tua bandot yang busuk. Dan, kepada Yoyok, ia tidak bisa memaafkan, bagaimana ia bisa mengizinkan hal ini. Tiba-tiba ia teringat semua cerita Mbak Rosa. Orang-orang yang telah diperbudak nafsu duniawi tidak lagi punya moral dan nilai harga diri. Yang ada dalam pikirannya hanya harta dan harta. (BBB, 2017: 214).

Dari kutipan di atas, terlihat id muncul sebagai seseorang yang sangat ingin memberontak. Ia sangat tidak suka dengan perilaku mertuanya yang seenaknya mempermainkan pernikahan. Namun id berhasil dilunakkan dengan adanya ego, Ayna sadar bahwa jika menolak perintah mertuanya, maka ia akan lebih kesulitan lagi mencari celah untuk dapat keluar dari status sebagai istri Yoyok. Adanya id dan ego juga memunculkan kejiwaan superego dimana ia tidak mau melawan perintah orang tua. Ayna tidak mau melanggar nasehat yang ia janjikan kepada almarhumah ibunya. Akhirnya Ayna menyetujui saja kemauan mertuanya itu.

\section{Nilai Pendidikan Karakter dalam Novel Bidadari Bermata Bening Karya Habiburrahman El Shirazy}

Karya sastra yang baik adalah karya sastra yang di dalamnya tidak hanya mengandung unsur hiburan, melainkan juga harus mengandung unsur-unsur nilai pendidikan karakter. Seorang pengarang atau penulis, dapat menyisipkan nilai pendidikan karakter di dalam karyanya secara tersurat maupun tersirat, sehingga hal ini dapat bermanfaat bagi pembaca.

Novel Bidadari Bermata Bening karya Habiburrahman El Shirazy juga terdapat nilai pendidikan karakter yang dapat diteladani dari para tokohnya. Nilai pendidikan karakter yang digunakan sebagai acuan penelitian ini adalah menggunakan nilai pendidikan karakter yang bersumber dari Kemendiknas (2010: 9). Dari 18 nilai pendidikan karakter yang tercantum dalam Kemendiknas tahun 2010, terdapat 13 nilai pendidikan karakter yang terdapat dalam novel Bidadari Bermata Bening. Nilai-nilai tersebut meliputi: religius, jujur, toleransi, disiplin, kerja keras, kreatif, mandiri, rasa ingin tahu, menghargai prestasi, bersahabat atau komunikatif, cinta damai, peduli sosial, dan tanggung jawab. Berikut beberapa cuplikan yang menunjukkan adanya nilai pendidikan karakter dalam novel Bidadari Bermata Bening.

Religius

"Syubhat atau haram! Ibadah saya nggak ada gunanya kalau ada barang haram masuk ke dalam perut saya jadi darah dan daging." (BBB, 2017: 189).

\section{Jujur}

"Injih, ada Abah. Saya bawa, ada di kamar. Tidak hanya surat nikah, foto-foto saat akad nikah dan fotofoto lainnya di Stockholm juga ada. Nanti saya tunjukkan. Atau saya ambil sekarang?" (BBB, 2017: 31). 


\section{Toleransi}

"Pakdemu setuju atau tidak, ummi dan abah akan mampir ke tempatmu pekan depan. Kau berkemaslah dan pulang sana!" (BBB, 2017: 94).

\section{Disiplin}

Ayna meneruskan pekerjaan $\mathrm{Bu}$ Nyai. Tinggal beberapa bungkus saja. Setelah itu ia kukus. Ia bersiap bersih-bersih badan. Ia baru sadar bahwa dirinya belum mandi. Usai shalat Shubuh ia langsung membantu memasak di dapur untuk ratusan santri, lalu ikut melayani para santriwati yang mengambil jatah sarapannya. (BBB, 2017: 10).

\section{Kerja Keras}

"Dia santri yang luar biasa. Yatim piatu. Ditinggal wafat ayahnya sejak dalam kandungan ibunya. Di pesantren ini, dia memikul pekerjaan yang lebih berat dari teman-teman seusianya. Dia khadimah. Dialah dan khadimah-khadimah yang lainnya yang setiap hari bangun lebih pagi dari yang lain untuk menyiapkan sarapan pagi para santri. Demi Allah, setiap pekerjaan yang dibebankan kepadanya diselesaikan dengan tuntas. Dia tidak akan menyerah sampai amanahnya tertunaikan. Meski sedemikian bebannya, dia berhasil menuliskan sejarah emas pesantren ini. Ketika ia diberi waktu untuk fokus belajar saat menghadapi UN, dia mampu mencetak prestasi yang belum pernah dicetak santri-santri sebelumnya. Yaitu meraih nilai UN 55,60. Bahasa Indonesia 8,9, Bahasa Inggris 9,5, Ekonomi 9,8, Matematika waduh ini edan banget, Matematika 10. Rata-rata nilainya 9,2. Ananda Ayna silakan maju." (BBB, 2017: 70).

\section{Kreatif}

...Ayna bukan jenis pekerja yang hanya menunggu perintah atasan. Ia adalah pekerja yang kreatif dan pikirannya jalan. Dalam waktu tidak lama, ia tahu jenis-jenis kue kesukaan sang majikan. Maka diamdiam di kamar kos-nya ia membuat adonan dan ia bawa ke kantor lalu ia masak dengan oven yang ada di dapur kantor. Begitu kue matang, ia hidangkan pada $\mathrm{Bu}$ Rosidah, dan tamu yang datang. Juga ia bagi pada teman-teman. Tak heran jika dirinya disayang oleh majikan dan dicintai oleh hampir semua karyawan. (BBB, 2017: 259).

\section{Mandiri}

"Ummi, Abah, ini Afif mohon pamit. Afif pergi seperti Imam Asy Syibli dulu pergi untuk memperbaiki dirinya. Jangan mencari Afif kalau satu tahun atau dua tahun tidak pulang. Kalau setelah tiga tahun Afif tidak pulang anggap saja Afif meninggal di jalan mencari ilmu. Afif mohon ridha Ummi dan Abah. Tanpa ridha itu, hidup Afif akan sengsara. Maafkan segala salah Afif." (BBB, 2017: 210).

\section{Rasa Ingin Tahu}

...apa sesungguhnya niat pakde dan budenya memperbaiki rumah itu? Apakah akan dijual? atau karena apa? Ia merasa ada yang aneh. (BBB, 2017: 100).

\section{Menghargai Prestasi}

...kata Romo Kyai Sobron, mangut buatan kamu paling enak yang pernah ia rasakan. (BBB, 2017: 8).

\section{Bersahabat/ Komunikatif}

"Iya, Alhamdulillah, dan aku harus berterima kasih padamu, Na. aku banyak tertolong oleh ringkasan yang kamu buat. Kau tahu sendiri 
kan menjelang UN aku sakit." (BBB, 2017: 14).

\section{Cinta Damai}

Ayna mendengar obrolan itu, tapi ia pura-pura tidak dengar. Selama mereka tidak ada yang benar-benar kurang ajar, ia tidak akan meladeni. Jika sedikit saja berbuat kurang ajar, meski Cuma sekedar mencolek, ia akan menghajarnya. Dan ia sangat yakin orang-orang pasar akan membelanya, sebab mereka sangat menghormati Kyai Sobron Ahsan Muslim. (BBB, 2017: 7).

\section{Peduli Sosial}

Ayna menamainya Bait Ibni Sabil, atau rumah anak jalanan. Karena memang rumah itu ia wakafkan untuk menampung anak-anak jalanan, dan kaum dhuafa. (BBB, 2017: 269).

\section{Tanggung Jawab}

Ternyata Pak Darsono tidak punya ikan tongkol. Ayna menyusuri seluruh bagian Pasar Pahing, ia tidak menemukan ikan tongkol. Ia merasa bertanggung jawab untuk mendapat ikan tongkol itu, maka setelah mendapatkan bumbu mangut dan bahan-bahan membuat bothok ia langsung mengendarai sepeda motornya ke rumah $\mathrm{Bu}$ Tuminah...(BBB, 2017: 9).

Nilai pendidikan karakter ini dapat dijadikan sebagai pedoman siswa untuk mengembangkan perilaku positif. Nilai pendidikan karakter yang terdapat dalam novel dapat dilihat dari perwatakan dan perilaku tokoh.

Kedudukan novel Bidadari Bermata Bening karya Habiburrahman ElShirazy dalam perspektif pembelajaran Bahasa Indonesia

Kedudukan novel Bidadari Bermata Bening karya Habiburrahman El-Shirazy dalam perspektif pembelajaran Bahasa
Indonesia dapat dijadikan sebagai materi pembelajaran Bahasa Indonesia kelas VIII SMP. Hal ini telah dijabarkan penulis dalam hasil penelitian. Novel ini memenuhi kriteria materi pembelajaran yang baik menurut Iskandarwassid dan Sunendar (2013: 222), yaitu: 1) materi atau bahan itu tepat (valid) untuk pencapaian tujuan pengajaran; 2) bahan ajar bermanfaat, artinya disesuaikan kebutuhan nyata dan tingkatan pendidikan peserta didik; 3) materi atau bahan pelajaran harus menarik; 4) materi atau bahan berada dalam batas kemampuan peserta didik.

Selain itu, novel ini memenuhi pendapat Rahmanto (1988) yang menjelaskan tentang pembelajaran sastra yang dapat membantu pendidikan secara utuh apabila cakupannya meliputi empat manfaat, yaitu 1) membantu keterampilan berbahasa; 2) meningkatkan pengetahuan budaya; 3 ) mengembangkan cipta dan rasa; serta 4) menunjang pembentukan karakter. Hal tersebut sejalan dengan pendapat Suhardini Nurhayati (dalam Wibowo, 2013:19) yang menyatakan bahwa pengajaran sastra pada umumnya secara hakiki membicarakan nilai hidup dan kehidupan yang mau tidak mau berkaitan langsung dengan pembentukan karakter manusia.

Berdasarkan hasil wawancara dengan guru Bahasa Indonesia di SMP Negeri 1 Banyudono mengenai kedudukan novel Bidadari Bermata Bening karya Habiburrahman El-Shirazy dalam perspektif pembelajaran Bahasa Indonesia dapat dijadikan sebagai materi pembelajaran Bahasa Indonesia kelas VIII SMP atau tidak, Ibu Sri Sudarmi mengatakan bahwa:

Menurut saya bisa, karena nilai-nilai karakter yang ada di dalam novel tersebut bisa dinukil sebagian, tidak semuanya karena memang ketika saya baca novel tersebut cocok untuk di tingkat yang lebih tinggi. Siswa-siswa yang sudah dewasa atau remaja (menginjak dewasa). Ini akan sangat bagus untuk siswa 
SMA. Kalau untuk tingkat SMP mungkin ada siswa yang belum "sampai" pemikirannya. Jadi, ada bagian-bagian tertentu yang sangat sesuai untuk anak-anak SMP. Misalnya kerja sama di lingkungan pesantren, ketaatan melaksanakan ibadah, penolong, dan seterusnya.

Novel Bidadari Bermata Bening karya Habiburrahman merupakan suatu karya sastra yang bermutu dan sangat baik digunakan sebagai bahan ajar mata pelajaran Bahasa Indonesia karena berisi nilai-nilai pendidikan karakter yang dapat memberikan dampak positif kepada siswa. Novel ini mengangkat cerita bagaimana semangat perjuangan seorang santriwati yatim piatu yang mampu bertahan hidup dengan menjadi seorang khadimah di rumah $\mathrm{Bu}$ Nyai, meski begitu ia mampu meraih prestasi UN terbaik nomor satu seJawa Tengah dan berhasil mencapai citacitanya. Sifat dan karakter yang dimiliki oleh Ayna sebagai pemeran utama serta selalu tabah dan ikhlas dalam menghadapi cobaan hingga pada akhirnya ia mendapat kebahagiaan atas segala kesabaran yang selama ini ia rasakan. Novel ini bisa memberikan pengaruh baik bagi setiap pembacanya

Sehingga dengan menggunakan novel ini secara tidak langsung pembaca atau siswa dapat meneladani cara pembentukan karakter Ayna tersebut. Ini menjadikan salah satu kelebihan dari novel Bidadari Bermata Bening bahwa novel ini bukan hanya menjadi novel pembangun jiwa, tetapi juga merupakan novel yang penuh dengan nilai pendidikan karakter, kelebihan dari novel ini belum tentu dimiliki oleh novel lain. Dengan banyaknya nilai pendidikan karakter yang dapat kita ambil dari novel Bidadari Bermata Bening, novel ini patut dijadikan sebagai alternatif bahan pembelajaran Bahasa Indonesia khususnya pada tingkat satuan pendidikan.

\section{SIMPULAN}

Berdasarkan pada penelitian yang telah dilakukan mengenai struktur, kajian psikologi sastra, nilai pendidikan karakter, dan menentukan kedudukan novel dalam perspektif pembelajaran Bahasa Indonesia.

Struktur novel Bidadari Bermata Bening terdiri dari tema, alur, tokoh dan penokohan, latar atau setting, dan sudut pandang. Masing-masing unsur tersebut memliki keterkaitan dengan unsur yang lain sehingga menjadikan novel Bidadari Bermata Bening karya Habiburrahman ElShirazy sebagai karya sastra yang baik. Keterpaduan tersebut memberikan pemahaman yang utuh bagi para pembaca.

Teori psikologi Sigmund Freud menyebutkan dalam diri mausia terdapat tiga komponen kejiwaan, yaitu $i d$, ego, dan superego. Dalam novel Bidadari Bermata Bening ini tokoh utama protagonis adalah Ayna mempunyai karakter $i d$, ego, dan superego yang seimbang. Novel ini mampu membangun jiwa para pembaca menjadi lebih baik karena terdapat banyak sifat baik yang bisa dicontoh dari tokoh utama.

Novel Bidadari Bermata Bening karya Habiburrahman El-Shirazy merupakan karya sastra yang dulce et utile, yaitu menghibur dan mendidik. Selain ceritanya yang menarik dan menghibur, juga terkandung nilai-nilai pendidikan karakter. Nilai pendidikan karakter tersebut meliputi religius, jujur, toleransi, disiplin, kerja keras, kreatif, mandiri, rasa ingin tahu, menghargai prestasi, bersahabat atau komunikatif, cinta damai, peduli sosial, dan tanggung jawab. Nilai-nilai tersebut dapat ditemui pada perwatakan maupun perilaku tokoh dalam novel.

Novel Bidadari Bermata Bening karya Habiburrahman El-Shirazy dapat digunakan sebagai materi pembelajaran Bahasa Indonesia di Sekolah Menengah Pertama karena sesuai dengan kompetensi dasar yang ada. Ini menjadikan salah satu kelebihan dari novel Bidadari Bermata Bening bahwa novel ini bukan hanya menjadi novel pembangun jiwa, tetapi juga 
merupakan novel yang penuh dengan nilai pendidikan karakter. Kelebihan dari novel ini belum tentu dimiliki oleh novel lain. Dengan banyaknya nilai pendidikan karakter yang dapat kita ambil dari novel Bidadari Bermata Bening, novel ini patut dijadikan sebagai alternatif bahan pembelajaran Bahasa Indonesia khususnya pada tingkat satuan pendidikan.

\section{REFERENSI}

Budiantoro, W. \& Wiwit M. (2016). Aplikasi Teori dan Psikologi Sastra (Kajian terhdap Puisi dan Kehidupan Penyair Abdul Wachid B.S.). Purwokerto: Penerbit Kaldera.

Emzir \& Saifur R. (2015). Teori dan Pengajaran Sastra. Jakarta: PT Raja Grafindo Persada.

Minderop, A. (2013). Psikologi Sastra: Karya Sastra, Metode, Teori, dan Contoh Kasus. Jakarta: Yayasan Pustaka Obor Indonesia.

Nurgiyantoro, B. (2012). Teori Pengkajian Fiksi. Yogyakarta: Gadjah Mada University Press.

Ratna, N. K. (2004). Teori, Metode dan Teknik Penelitian Sastra. Yogyakarta: Pustaka Pelajar.

Teeuw, A. (2015). Sastra dan Ilmu Sastra: Pengantar Teori Sastra. Bandung: PT. Dunia Pustaka Jaya.

Wibowo, A. (2013). Pendidikan Karakter Berbasis Sastra. Yogyakarta: Pustaka Belajar.

Winkel, W.S. (2009). Psikologi Pengajaran. Yogyakarta: Media Abadi.
Dari hasil penelitian ini, peneliti menyarankan guru-guru Bahasa Indonesia untuk menggunakan novel Bidadari Bermata Bening karya Habiburrahman El Shirazy sebagai materi pembelajaran sastra di sekolah. Selain itu, baik guru maupun sekolah, perlu menyediakan bahan bacaan yang sesuai dengan perkembangan usia anak. 